\title{
HUBUNGAN KARAKTERISTIK PEKERJA, KELENGKAPAN DAN HIGIENITAS APD DENGAN KEJADIAN DERMATITIS KONTAK (STUDI KASUS DI RUMAH KOMPOS JAMBANGAN SURABAYA)
}

\author{
Shenna Fielrantika, Anggraitya Dhera \\ Departemen Kesehatan Lingkungan \\ Fakultas Kesehatan Masyarakat Universitas Airlangga \\ Email: shennachena@yahoo.com
}

\begin{abstract}
Contact dermatitis is an inflammation of skin which is caused by a substance that sticks to somebody's skin. The cause of contact dermatitis is physical factor, a substance of plants, and other chemicals. One of prevention contact dermatitis because of working is the usage of personal protection equipments like mask, gloves, goggles, shoes, and body protection. The objectives of this research was to analyze the relation between the characteristics of worker, the completeness and the hygiene of personal protection equipments with the contact dermatitis occurrence in the house of compost Jambangan Surabaya. The methodology of this research was observational using cross sectional approach. The target of this research was all workers who have worked in the house of compost Jambangan Surabaya as 21 people were taken by total sampling technique. The variable that was observed included contact dermatitis occurrence, gender, the history of skin allergy, age, knowledge, attitude, action, and the completeness of using personal protection equipments. The primer data was taken by interview with questionnaire paper and observation. The secondary data was taken from the house of compost Jambangan Surabaya. Then, data that was taken from questionnaire was analyzed by descriptive as the narration form. The result of this research explained that the completeness of using personal protection equipments by the worker have not completed yet and for the main characteristics of the worker was their knowledge. The conclusion was using complete personal protection equipments could prevent contact dermatitis of the worker in the house of compost Jambangan Surabaya.
\end{abstract}

Keywords: individual characteristics, Completeness and the hygiene of Personal Protection Equipments, contact dermatitis

\begin{abstract}
ABSTRAK
Dermatitis kontak merupakan peradangan kulit disebabkan oleh suatu bahan yang menempel pada kulit seseorang. Penyebab dermatitis kontak yaitu faktor fisik, bahan dari tumbuhan, dan bahan kimia lainnya. Salah satu pencegahan dermatitis kontak akibat kerja yaitu penggunaan alat pelindung diri (APD) seperti masker, sarung tangan, kacamata, sepatu, dan pakaian kerja. Penelitian ini bertujuan untuk menganalisis hubungan karakteristik pekerja, kelengkapan dan higienitas alat pelindung diri dengan kejadian dermatitis kontak di Rumah Kompos Jambangan Surabaya. Metode penelitian ini adalah observasional dengan pendekatan cross sectional. Sasaran penelitian ini adalah semua pekerja yang bekerja di Rumah Kompos Jambangan Surabaya sebanyak 21 orang dengan teknik total sampling. Variabel yang diteliti meliputi kejadian dermatitis kontak, jenis kelamin, riwayat alergi kulit, usia, pengetahuan, sikap, tindakan, dan kelengkapan pemakaian alat pelindung diri (APD). Data primer diperoleh melalui wawancara dengan lembar kuesioner dan observasi. Data sekunder diperoleh dari pihak Rumah Kompos Jambangan Surabaya. Kemudian data yang diperoleh dari kuesioner dianalisis secara deskriptif dalam bentuk narasi. Hasil penelitian menyatakan bahwa kelengkapan pemakaian alat pelindung diri oleh pekerja belum terlaksana dengan lengkap dan untuk karakteristik pekerja yang utama adalah pengetahuan pekerja. Kesimpulannya adalah pemakaian alat pelindung diri yang lengkap dapat mencegah terjadinya dermatitis kontak pekerja di rumah kompos Jambangan Surabaya.
\end{abstract}

Kata kunci: karakteristik individu, kelengkapan dan higienitas APD, dermatitis kontak

\section{PENDAHULUAN}

Sampah merupakan salah satu permasalahan yang sangat kompleks yang sedang dihadapi berbagai negara baik itu negara berkembang maupun negara maju di dunia. Masalah sampah adalah masalah yang harus segera ditangani, hal ini disebabkan banyaknya keberadaan tumpukan sampah yang telah dihasilkan dari berbagai aktivitas yang dilakukan. Pengertian sampah itu sendiri adalah suatu benda yang dibuang karena sudah tidak dapat terpakai dan tidak dapat digunakan lagi. 
Permasalahan sampah juga dialami oleh beberapa kota besar yang ada di Indonesia salah satunya adalah Surabaya, di mana Surabaya merupakan kota metropolitan terbesar kedua di Indonesia yang mana setiap harinya kota tersebut menghasilkan sampah dalam jumlah yang sangat besar pula. Pengelolaan sampah di Surabaya dilakukan secara struktural dan pengelolaan ini merupakan tanggung jawab Dinas Kebersihan dan Pertamanan Kota Surabaya. Berdasarkan data Dinas Kebersihan dan Pertamanan Kota Surabaya pada tahun 2014, total hasil dari timbunan sampah yang dihasilkan Kota Surabaya yaitu $9.468 \mathrm{~m}^{3} /$ hari. Karakteristik sampah didominasi sampah organik sebesar $68,5 \%$ dan sisanya merupakan sampah anorganik seperti plastik, logam, gelas atau kaca, dan kertas. Jumlah sampah yang masuk ke TPA rata-rata \pm 1400 ton/hari. Sampah yang dihasilkan ini berasal dari aktivitas makhluk hidup terutama manusia baik dari industri, rumah tangga, perkantoran, dan aktivitas lainnya. Masalah sampah yang ada di Kota Surabaya memang merupakan problem yang sangat sulit untuk diatasi secara langsung, hal ini dikarenakan proses daur ulang atau penghancuran sampah khususnya sampah non organik memerlukan waktu yang cukup lama bahkan sampai bertahun-tahun untuk proses tersebut. Oleh karena itu, Pemerintahan Kota Surabaya membangun UDPK (Usaha Daur Ulang dan Produksi Kompos) sejak tahun 2011 di bawah tanggung jawab Sarana dan Prasarana Dinas Kebersihan dan Pertamanan (DKP) Kota Surabaya.

Ide dasar pembangunan rumah kompos ini adalah sebagai pemanfaatan sampah organik yang dihasilkan agar dapat di daur ulang dan tidak terbuang sia-sia sehingga meminimalisirkan lingkungan Kota Surabaya dari sampah organik. Rumah kompos ini menampung hasil sampah organik yang berasal dari penyapuan jalan, sampah pasar, dan sampah dari perampingan pohon di tepi jalan. Sampah ini akan diolah sebagai bahan baku pembuatan kompos yang kemudian hasil kompos ini digunakan untuk penghijauan taman kota yang ada di Surabaya.

Pada tahun 2016, Dinas Kebersihan dan Pertamanan Kota Surabaya telah mendirikan sebanyak 26 unit rumah kompos yang telah aktif dan dioperasikan guna menanggulangi permasalahan sampah yang ada di Surabaya. Dalam pengolahan sampah sampai menjadi kompos, rumah kompos memerlukan tempat pengomposan yang sesuai dengan banyaknya asupan sampah organik yang akan diolah. Di samping itu, rumah kompos juga harus memantau suhu tumpukan sampah tersebut dalam proses pembuatan kompos. Suhu yang dihasilkan dari pengomposan tersebut memiliki risiko dampak lingkungan yang dapat mempengaruhi lingkungan fisik udara tempat kerja sehingga di rumah kompos tersebut harus memperhatikan lingkungan fisik udara baik dalam proses pengomposan dan di tempat kerja yang sesuai dengan Kepmenkes Republik Indonesia No.1405 Tahun 2002 Tentang Persyaratan Kesehatan Lingkungan Kerja Perkantoran dan Industri.

Proses pengolahan kompos di rumah kompos ini tidak menutup kemungkinan juga dapat menyebabkan terjadinya risiko penyakit pada pekerjanya antara lain adalah penyakit dermatitis kontak. Menurut Djuanda (2007), dermatitis kontak adalah peradangan kulit yang terjadi akibat bahan/ substansi yang kontak langsung dan menempel pada kulit. Dermatitis kontak mempunyai dua macam jenis yaitu dermatitis kontak iritan dan dermatitis kontak alergik, kedua macam dermatitis kontak tersebut dapat bersifat akut maupun kronis. Penyakit dermatitis kontak mempunyai gejala atau ciri pada kulit yaitu nampak kemerahan pada kulit, kulit menjadi bengkak, terdapat vesikel kecil yang berisi cairan dan pada tahap akut kulit dapat mengeluarkan cairan. Pada tahap kronis, kulit akan menjadi bersisik, mengalami likenifikasi, kulit menjadi menebal, terasa kasar dan retak-retak, serta kulit dapat berubah warna.

Data tentang prevalensi penyakit kulit khususnya dermatitis kontak sulit untuk didapatkan baik di negara maju dan negara berkembang. Berdasarkan penelitian yang dilakukan WHO pada tahun 1999 dalam Dinkes Surabaya (2014) tentang penyakit yang dialami pekerja saat bekerja memperlihatkan bahwa penyakit kulit (dermatitis) akibat kerja menempati posisi urutan keempat yaitu dengan persentase sekitar $10 \%$ yang didapat dari 5 (lima) benua. Menurut Ariesa saat melakukan penelitian pada tahun 2010 di rumah kompos Bratang Surabaya, didapatkan hasil terhadap keluhan penyakit pekerja selama bekerja dalam proses pengolahan sampah organik hingga menjadi kompos di rumah kompos Bratang Surabaya bahwa penyakit kulit dengan keluhan alergi kulit urutan ketiga sebesar $70 \%$ dan keluhan kulit kemerahan urutan keenam sebesar $40 \%$.

Dalam menurunkan angka terjadinya penyakit dermatitis kontak akibat pekerjaan, salah satu pencegahan yang dapat dilakukan untuk mengurangi terjadinya penyakit dermatitis kontak adalah 
penggunaan alat pelindung diri (APD) saat bekerja. Alat pelindung diri mempunyai manfaat untuk melindungi bagian tubuh pekerja yang fungsinya melindungi sebagian atau seluruh tubuh dari potensi bahaya paparan dari luar di tempat kerja. Alat pelindung diri yang dimaksud yaitu meliputi sarung tangan, masker, sepatu dan pakaian kerja. Namun, selain alat pelindung diri, tindakan yang sangat perlu diperhatikan adalah memelihara kebersihan dan kesehatan seseorang (personal hygiene) yang berguna dalam mencegah terjadinya dermatitis kontak.

Rumah Kompos Jambangan Surabaya juga merupakan tempat pengolahan kompos yang terdapat proses pemilahan sampah langsung dan pengolahan sampah dengan cara teknik pengomposan. Berdasarkan hasil survei langsung saat berada di Rumah Kompos Jambangan Surabaya, para pekerja mengeluh adanya penyakit kulit seperti alergi, gatalgatal dan kulit memerah setelah pekerja berkontak langsung dengan sampah baik itu dalam proses pemilahan sampah dan pengolahan kompos. Keluhan pekerja tersebut merupakan gejala dermatitis kontak. Namun, pekerja tidak mengetahui gejala tersebut merupakan gejala penyakit dermatitis kontak. Pekerja beranggapan bahwa gejala tersebut hal yang biasa dan akan segera sembuh. Kurangnya pengetahuan tentang dermatitis kontak dapat memperparah penyakit kulit pekerja tersebut serta kurangnya kesadaran pekerja dalam hal penggunaan alat pelindung diri dan personal hygiene juga dapat menyebabkan dermatitis kontak semakin parah.

Tujuan umum penelitian ini adalah untuk menganalisis kelengkapan pemakaian alat pelindung diri (APD), dan karakteristik individu terhadap kejadian dermatitis kontak pekerja di Rumah Kompos Jambangan Surabaya. Tujuan khusus dalam penelitian ini yaitu mengidentifikasi kelengkapan pemakaian APD (alat pelindung diri) pekerja Rumah Kompos Jambangan Surabaya; mengidentifikasi karakteristik individu (jenis kelamin, riwayat alergi kulit, usia pekerja), dan pengetahuan, serta sikap pekerja mengenai penyakit dermatitis kontak di Rumah Kompos Jambangan Surabaya; mengidentifikasi personal hygiene pekerja Rumah Kompos Jambangan Surabaya; menganalisis hubungan kelengkapan pemakaian alat pelindung diri dan karakteristik individu pekerja Rumah Kompos Jambangan Surabaya dengan penyakit dermatitis kontak.

\section{METODE}

Penelitian ini merupakan penelitian observasional dengan desain rancang bangun penelitian yang digunakan adalah rancangan survei cross sectional. Penelitian ini dilaksanakan di Rumah Kompos Jambangan Surabaya yang merupakan sebuah tempat pengolahan kompos yang beralamat di Jalan Jambangan Kebonagung I Surabaya dan waktu penelitian dilakukan antara bulan Mei 2016 sampai dengan bulan November 2016. Sasaran dalam penelitian ini adalah semua pekerja yang bekerja di Rumah Kompos Jambangan Surabaya sebanyak 21 orang baik di area pemilahan sampah dan area pengomposan. Teknik pengambilan sampel dalam penelitian ini adalah total sampling yang dikarenakan jumlah populasi kurang dari 100 sehingga seluruh populasi dijadikan sampel penelitian (Sugiyono, 2007). Dalam penelitian ini variabel yang diteliti berupa variabel bebas dalam penelitian ini meliputi jenis kelamin, riwayat alergi kulit, usia, pengetahuan, sikap, tindakan, dan penggunaan alat pelindung diri. Variabel terikat dalam penelitian ini adalah kejadian dermatitis kontak. Data yang digunakan dalam penelitian ini adalah data primer dan data sekunder. Data primer diperoleh melalui wawancara dengan lembar kuesioner dan lembar observasi. Kuesioner tersebut ditujukan kepada semua responden. Untuk data sekunder diperoleh dari instansi terkait dengan penelitian, yaitu pihak Rumah Kompos Jambangan Surabaya. Kemudian data yang diperoleh dari kuesioner dianalisis secara deskriptif dalam bentuk narasi.

\section{HASIL}

\section{Gambaran Umum Rumah Kompos}

Rumah Kompos Jambangan Surabaya atau TPS 3R merupakan tempat penampungan sampah sementara yang mempunyai tempat pemilahan sampah dan pengolahan kompos. Namun, TPS 3R Jambangan dalam penelitian ini disebut sebagai Rumah Kompos Jambangan. Rumah Kompos Jambangan Surabaya ini dibangun dan beroperasi tahun 2010 yang berlokasi di Jl. Jambangan Kebonagung I Surabaya. Luas bangunan yaitu $148,75 \mathrm{~m}^{2}$ dengan kapasitas $6 \mathrm{~m}^{3} /$ hari. Kegiatan yang dilakukan di Rumah Kompos Jambangan Surabaya yaitu proses pemilahan sampah dan proses pembuatan kompos. Sampah yang digunakan dalam 
pembuatan kompos ini merupakan bahan yang berasal dari penyapuan jalan, sampah pasar, dan sampah rumah tangga. Salah satu bahan pembuatan kompos yang berasal dari sampah rumah tangga warga sekitar Jambangan ini akan dipilah terlebih dahulu untuk dibedakan antara sampah organik untuk campuran bahan kompos dan sampah non organik untuk dijual lagi kepada pengepul sedangkan sisa sampah (residu) yang tidak terpakai akan dikirim ke TPA Benowo.

Bahan baku pembuatan kompos ini hanya menggunakan sampah organik dan teknik yang digunakan dalam proses pembuatan kompos ini menggunakan teknik open windrow. Teknik open windrow merupakan teknik yang digunakan dalam proses perubahan bahan organik sehingga menjadi bahan atau materi yang stabil melalui reaksi biologis mikroorganisme secara aerobik dalam kondisi yang terkendali.

Sampah organik yang diproses menjadi kompos, berlangsung selama \pm 20 hari yang dilakukan secara alami. Hasil produksi kompos yang dihasilkan Rumah Kompos Jambangan Surabaya sebanyak 2 $\mathrm{m}^{3} /$ hari dengan jumlah tenaga kerja sebanyak 21 orang dimana 5 orang pekerja di area pengomposan dan 16 orang pekerja di area pemilahan sampah. Namun, di rumah kompos tersebut terdapat 2 orang pengawas yang berasal dari pegawai Dinas Kebersihan dan Pertamanan, akan tetapi pengawas tersebut tidak secara full time berada di rumah kompos tersebut. Hal ini disebabkan karena para pengawas tidak hanya mempunyai tanggung jawab mengawasi hanya satu rumah kompos melainkan pengawas harus mengawasi dan berpindah-pindah antara rumah kompos satu ke rumah kompos satu lainnya.

Untuk rata-rata per bulan pemasukan bahan baku kompos pada Rumah Kompos Jambangan Surabaya didapatkan hasil dari berbagai sumber bahan baku yaitu berasal dari perantingan sebesar $153 \mathrm{~m}^{3}$, pemeliharaan taman sebesar $12 \mathrm{~m}^{3}$, dan dari sampah pasar sebesar $8 \mathrm{~m}^{3}$. Rata-rata per bulan bahan yang masuk dan yang dapat diolah sebesar $121 \mathrm{~m}^{3}$ kemudian bahan yang tidak dapat diolah sebesar $52 \mathrm{~m}^{3}$.

Proses pengolahan sampah di Rumah Kompos Jambangan Surabaya adalah sebagai berikut: (1) Sampah datang dari warga dan petugas kebersihan. Untuk sampah dari warga berupa sampah rumah tangga baik organik dan non organik sedangkan sampah dari petugas kebersihan merupakan sampah organik yang berasal dari penyapuan jalan, pemotongan daun dan ranting. (2) Pemilahan sampah rumah tangga yang berasal dari warga dipilah menggunakan conveyor belt sedangkan sampah yang berasal dari pemotongan daun dan ranting langsung dimasukkan ke alat pencacah. (3) Untuk sampah non organik di press dan di packing untuk dijual kembali. (4) Kemudian sampah organik diteruskan ke alat penghalus untuk kemudian dijadikan bahan pembuatan kompos. (5) Sisa sampah (residu) yang tidak dapat diolah dimasukkan ke kontainer lalu dikirim ke TPA Benowo.

Setelah kompos tersebut jadi, pendistribusian dilakukan secara langsung untuk digunakan keperluan pemupukan taman Kota Surabaya. Kompos yang diproduksi oleh Rumah Kompos Jambangan Surabaya tidak untuk diperjualbelikan. Sehingga, warga bebas untuk menggunakan kompos tersebut secara gratis.

\section{Kejadian Penyakit Dermatitis Kontak di Rumah Kompos Jambangan Surabaya}

Penyakit dermatitis kontak yang terjadi pada pekerja di Rumah Kompos Jambangan Surabaya berdasarkan hasil pemeriksaan keluhan pekerja yang telah dilakukan oleh dokter umum didapatkan hasil bahwa dari 21 orang $(100 \%)$ pekerja yaitu sebesar 16 orang $(76,2 \%)$ pekerja mengalami dermatitis kontak sedangkan 5 orang $(23,8 \%)$ pekerja tidak mengalami dermatitis kontak.

Sebanyak 16 orang $(76,2 \%)$ pekerja yang mengalami dermatitis kontak tersebut, responden mengeluhkan gejala dermatitis kontak antara lain sebesar 9 orang $(42,9 \%)$ mengalami iritasi kulit dalam 1 bulan terakhir, 5 orang $(23,8 \%)$ yang mengeluh mengalami iritasi setelah bekerja yang berkontak langsung dengan sampah, 1 orang $(4,8 \%)$ mengalami kulit bengkak, 15 orang $(71,4 \%)$ mengalami kulit yang kemerahan dan timbul rasa gatal di area kulit di mana kedua gejala ini adalah gejala yang paling banyak dikeluhkan oleh pekerja, 4 orang $(19,0 \%)$ mengalami adanya keluhan vesikel (tonjolan berisi cairan diameter $<5 \mathrm{~mm}$ ), 12 orang $(57,1 \%)$ mengeluhkan adanya papul (tonjolan padat), 14 orang $(66,7 \%)$ mengeluhkan kulit yang kering dan bersisik, dan sebanyak 2 orang $(9,5 \%)$ mengeluhkan kulit yang terasa perih dan sakit. Gejala dermatitis kontak tersebut dikeluhkan pekerja setelah mereka kontak dengan sampah dan selesai bekerja. 


\section{Kelengkapan Pemakaian Alat Pelindung Diri (APD)}

Rumah Kompos Jambangan Surabaya merupakan tempat kerja di mana tempat tersebut digunakan untuk pengolahan kompos. Selama mengolah kompos pekerja diharuskan memakai alat pelindung diri yang terdiri dari sarung tangan, masker, sepatu, dan pakaian kerja yang digunakan pekerja saat berkontak langsung dengan bahan baku kompos dan alat pelindung diri ini telah disediakan oleh pihak Rumah Kompos Jambangan. Sebanyak 21 pekerja $(100 \%)$ ada yang lengkap memakai alat pelindung diri namun ada juga yang jarang atau tidak lengkap memakai alat pelindung diri, untuk kelengkapan pemakaian sarung tangan sebanyak 16 orang $(76,2 \%)$ pekerja memakai sarung tangan dan sebanyak 5 orang $(23,8 \%)$ tidak memakai sarung tangan, untuk kelengkapan pemakaian masker sebanyak 6 orang $(28,6 \%)$ pekerja memakai masker dan 15 orang $(71,4 \%)$ pekerja tidak memakai masker. Untuk kelengkapan pemakaian sepatu sebanyak 8 orang $(38,1 \%)$ pekerja memakai sepatu dan 13 orang $(61,9 \%)$ pekerja tidak memakai sepatu saat bekerja. Kemudian, untuk kelengkapan pemakaian pakaian kerja saat bekerja, sebanyak 15 orang $(71,4 \%)$ pekerja memakai pakaian kerja dan sebanyak 6 orang $(28,6 \%)$ tidak memakai pakaian kerja.

\section{Karakteristik Pekerja Rumah Kompos Jambangan Surabaya}

Total populasi pekerja yang bekerja di Rumah Kompos Jambangan Surabaya sekitar 21 orang $(100 \%)$. Karakteristik individu dalam penelitian ini meliputi serta jenis kelamin, riwayat alergi kulit keluarga, usia, pengetahuan, sikap, tindakan, serta penggunaan alat pelindung diri (APD).

\section{Jenis Kelamin Pekerja Rumah Kompos Jambangan Surabaya}

Hasil penelitian diketahui bahwa jenis kelamin yang bekerja di Rumah Kompos Jambangan Surabaya mayoritas adalah berjenis kelamin lakilaki sebanyak 15 orang $(71,4 \%)$ namun terdapat pula pekerja wanita sebanyak 6 orang $(28,6 \%)$. Walaupun jumlah pekerja wanita tidak sebanyak pekerja laki-laki, pekerjaan tidak dibedakan namun pekerja wanita hanya dipekerjakan di area pemilahan kompos sedangkan di area kompos lebih banyak dikerjakan oleh pekerja laki-laki.

\section{Riwayat Alergi Kulit Pekerja Rumah Kompos Jambangan Surabaya}

Berdasarkan riwayat alergi kulit pada pekerja Rumah Kompos Jambangan Surabaya, baik yang mengalami dermatitis kontak maupun yang tidak mengalami dermatitis kontak didapatkan hasil bahwa dari 21 orang (100\%) pekerja tidak ada yang mempunyai riwayat alergi kulit baik responden maupun orang tua responden.

\section{Usia Pekerja Rumah Kompos Jambangan Surabaya}

Usia pekerja yang ada di Rumah Kompos Jambangan Surabaya yang termuda berusia 18 tahun sedangkan usia tertua yaitu 75 tahun. Berdasarkan 21 orang $(100 \%)$ tersebut, sebanyak 18 orang $(85,7 \%)$ pekerja berusia $15-39$ tahun. Di mana usia tersebut yang paling banyak bekerja di Rumah Kompos Jambangan Surabaya. Kemudian sebanyak 2 orang $(9,5 \%)$ pekerja memiliki usia $40-64$ tahun. Untuk usia $>64$ tahun hanya 1 orang $(4,8 \%)$ dan merupakan usia yang paling tua.

\section{Pengetahuan Pekerja Rumah Kompos Jambangan Surabaya}

Pengetahuan pekerja di Rumah Kompos Jambangan Surabaya tentang dermatitis kontak didapatkan rata-rata hasil yaitu dalam kategori sedang. Sebanyak 21 orang (100\%) pekerja dengan nilai terbanyak mendapatkan kategori sedang karena tidak mengetahui pengertian dan penyebab dermatitis kontak sebesar 10 orang $(47,6 \%)$ sedangkan nilai yang sedikit masuk dalam kategori kurang karena pekerja tidak mengetahui pengertian, penyebab dan gejala dermatitis kontak sebesar 3 orang (14,3\%). Namun ada juga pekerja yang memperoleh nilai pengetahuan baik yaitu sebesar 8 orang $(38,1 \%)$.

\section{Sikap Pekerja Rumah Kompos Jambangan Surabaya}

Sikap pekerja di Rumah Kompos Jambangan Surabaya tentang dermatitis kontak didapatkan ratarata hasil yaitu dalam kategori baik. Sebanyak 21 orang $(100 \%)$ pekerja yang mendapatkan kategori baik sebanyak 17 orang $(81,0 \%)$ telah merespons baik akan pencegahan dermatitis kontak secara positif yang ada pada diri pekerja yang berhubungan dengan dermatitis kontak, sedangkan sisanya masuk dalam kategori sedang sebanyak 4 orang $(19,0 \%)$ 
karena kurang dapat merespons secara baik dalam hal pencegahan yang berhubungan dengan dermatitis kontak.

\section{Tindakan Pekerja Rumah Kompos Jambangan Surabaya}

Tindakan personal hygiene pekerja di Rumah Kompos Jambangan Surabaya terhadap dermatitis kontak didapatkan hasil yaitu dalam kategori baik. Sebanyak 21 orang $(100 \%)$ pekerja yang mendapatkan kategori baik karena pekerja selalu menjaga kebersihan dalam personal hygiene. Namun, dalam hal mencuci tangan sebanyak 18 orang $(85,7 \%)$ pekerja mencuci tangan saat hanya sebelum makan dan sebanyak 14 orang $(66,6 \%)$ pekerja menggunakan air tidak mengalir saat mencuci tangan namun pekerja menggunakan sabun hal ini disebabkan karena minimnya fasilitas sanitasi yang ada di rumah kompos.

Tindakan pemakaian APD pekerja di Rumah Kompos Jambangan Surabaya terhadap dermatitis didapatkan sebanyak 16 orang $(76,2 \%)$ dalam kategori sedang. Hal ini disebabkan karena dalam pemakaian alat pelindung diri (APD), mereka jarang menggunakan APD yang lengkap seperti sarung tangan, sepatu, masker, dan pakaian kerja.

\section{Hubungan Kelengkapan Pemakaian Alat Pelindung Diri (APD) terhadap Kejadian Dermatitis Kontak}

Berdasarkan observasi secara langsung, hasil penelitian menunjukkan bahwa pekerja yang lengkap menggunakan alat pelindung diri sebanyak 5 orang $(23,8 \%)$ dan yang tidak lengkap menggunakan alat pelindung diri sebanyak 16 orang $(76,2 \%)$.

Sebanyak 5 orang $(23,8 \%)$ yang lengkap menggunakan alat pelindung diri ada 2 orang $(9,5 \%)$ yang mengalami dermatitis kontak dan 3 orang $(14,3 \%)$ yang lengkap menggunakan alat pelindung diri tidak mengalami penyakit dermatitis kontak. Lalu dari 16 orang $(76,2 \%)$ pekerja yang tidak lengkap menggunakan alat pelindung diri, didapatkan hasil sebanyak 14 orang $(66,7 \%)$ yang tidak lengkap memakai alat pelindung diri mengeluhkan adanya gejala dermatitis kontak setelah bekerja dan berkontak langsung dengan sampah. Sebanyak 2 orang $(9,5 \%)$ tidak memakai alat pelindung diri dan tidak mengalami dermatitis kontak.

\section{Hubungan Karakteristik Pekerja terhadap Kejadian Penyakit Dermatitis Kontak}

Berdasarkan hasil penelitian jenis kelamin pekerja di Rumah Kompos Jambangan Surabaya didapatkan hasil bahwa pekerja berjenis kelamin laki-laki yang mengalami dermatitis kontak sebanyak 14 orang $(66,7 \%)$. Pekerja dengan jenis kelamin perempuan yang mengalami dermatitis kontak sebanyak 2 orang $(9,5 \%)$ kemudian hasil penelitian riwayat alergi kulit pekerja di Rumah Kompos Jambangan Surabaya, para pekerja baik yang mengalami dermatitis kontak maupun yang tidak mengalami dermatitis kontak didapatkan bahwa tidak ada yang memiliki riwayat alergi kulit yang dapat menyebabkan dermatitis kontak.

Hasil penelitian usia pekerja terhadap kejadian dermatitis kontak di Rumah Kompos Jambangan Surabaya adalah usia pekerja 15-39 tahun yang mengalami dermatitis kontak terdapat sebanyak 15 orang $(71,4 \%)$ dan yang tidak mengalami dermatitis kontak sebanyak 3 orang (14,3\%). Kemudian, pekerja yang berusia 40-64 tahun yang mengalami dermatitis kontak terdapat 1 orang $(4,8 \%)$ dan 1 orang $(4,8 \%)$ lainnya tidak mengalami penyakit dermatitis kontak. Lalu 1 orang $(4,8 \%)$ lagi tidak mengalami dermatitis kontak dan pekerja tersebut yang berusia $>64$ tahun.

Berdasarkan hasil penelitian menurut pengetahuan pekerja di Rumah Kompos Jambangan Surabaya yang termasuk dalam kategori sedang dan mengalami dermatitis kontak sebanyak 10 orang $(47,6 \%)$, hal ini terjadi karena para pekerja kurang memahami dermatitis kontak dari aspek pengertian dan penyebab dermatitis kontak. Pekerja dengan kategori baik yang mengalami dermatitis kontak sebanyak 3 orang $(14,3 \%)$ dan yang tidak mengalami dermatitis kontak sebanyak 5 orang $(23,8 \%)$, hal ini terjadi karena mereka mengetahui dampak pekerjaan mereka yang dapat menyebabkan dermatitis kontak sehingga mereka lebih memahami bagaimana cara pencegahan. Lalu sebanyak 3 orang (14,3\%) pekerja mendapatkan kategori kurang yang mengalami dermatitis kontak, hal ini dikarenakan mereka belum memahami tentang dermatitis kontak

Sikap pekerja di Rumah Kompos Jambangan Surabaya masuk dalam kategori baik dan mengalami dermatitis kontak sebanyak 12 orang $(57,1 \%)$, ini disebabkan karena pekerja mengetahui cara pencegahan dermatitis tapi tidak menerapkan 
dalam bekerja. Sebanyak 5 orang $(23,8 \%)$ yang tidak mengalami dermatitis kontak, mereka telah mengetahui cara pencegahan dampak dari pekerjaan tersebut yang dapat mencegah dermatitis kontak. Namun, sisanya sebanyak 4 orang $(19,0 \%)$ masuk dalam kategori sedang dan mengalami dermatitis kontak.

Tindakan pekerja di Rumah Kompos Jambangan Surabaya dalam personal hygiene masuk dalam kategori baik. Sebanyak 16 orang $(76,2 \%)$ mengalami adanya dermatitis kontak dan 5 orang $(23,8 \%)$ tidak mengalami dermatitis kontak. Tindakan penggunaan APD dari 21 (100\%) pekerja, didapatkan dalam kategori baik sebanyak 2 orang $(9,5 \%)$ mengalami dermatitis kontak dan 3 orang $(14,3 \%)$ tidak mengalami dermatitis kontak. Untuk kategori sedang, sebanyak 14 orang $(66,7 \%)$ mengalami dermatitis kontak dan 2 orang $(9,5 \%)$ tidak mengalami dermatitis kontak.

\section{PEMBAHASAN}

\section{Kejadian Penyakit Dermatitis Kontak di Rumah Kompos Jambangan Surabaya}

Menurut Djuanda (2007), Dermatitis kontak merupakan peradangan kulit atau dermatitis yang disebabkan oleh bahan/substan yang menempel pada kulit. Dermatitis kontak mempunyai beberapa jenis yaitu dermatitis kontak iritan dan dermatitis kontak alergi, keduanya dapat bersifat akut maupun kronis. Di mana, penyebab dermatitis kontak akibat kerja dibedakan beberapa penyebab yaitu fisik, bahan yang berasal dari tumbuhan, makhluk hidup, dan bahan kimia lainnya. Dermatitis kontak dapat dialami oleh seseorang dan sering kali terdapat pada tangan, leher, paha, badan, wajah, telinga dan lengan. Gejala dermatitis kontak yang sering dikeluhkan yaitu meliputi adanya rasa gatal, mengalami kulit bengkak, kemerahan, adanya keluhan vesikel (tonjolan berisi cairan diameter $<5 \mathrm{~mm}$ ), adanya papul (tonjolan padat), kulit yang kering dan bersisik, serta kulit terasa perih dan sakit.

Berdasarkan hasil penelitian keluhan gejala dermatitis kontak yang dialami oleh pekerja di Rumah Kompos Jambangan Surabaya jenis keluhan yang paling banyak dialami atau dikeluhkan pekerja saat berkontak langsung maupun selesai bekerja yaitu sebesar 71,4\% mengeluhkan kulit yang kemerahan dan gatal pada kulit. Sebesar $66,7 \%$ mengeluhkan kulit yang kering dan bersisik. Sebesar $57,1 \%$ terdapat adanya papul (tonjolan padat).
Keempat gejala dermatitis tersebut yang dihasilkan berdasarkan hasil pemeriksaan dokter di mana walaupun hanya ada satu gejala yang timbul dapat dikatakan sebagai dermatitis kontak.

Gejala dermatitis kontak yang dialami pekerja ini dikeluhkan pekerja sesaat mereka selesai bekerja. Dimana tugas pekerja di Rumah Kompos Jambangan Surabaya yaitu memilah sampah dan membuat kompos yang berasal dari hasil pemilahan sampah warga yang kemudian akan dijadikan bahan pembuatan kompos. Saat bekerja memilah sampah dan pembuatan kompos, para pekerja berkontak langsung dengan substan/bahan sampah yang dapat menyebabkan terjadinya gejala dermatitis kontak ini. Hampir semua pekerja yang ada disana tidak memakai alat pelindung diri yang lengkap dan kurang sadar akan kesehatan sehingga kemungkinan terjadinya gejala dermatitis kontak sangat besar terjadi akibat tidak memakai alat pelindung diri yang lengkap saat berkontak langsung dengan substan/ bahan sampah. Sehingga, perlunya kesadaran pekerja dan pihak pengawas secara tegas dalam pencegahan dermatitis kontak dengan salah satunya pemakaian alat pelindung diri yang lengkap seperti sarung tangan, masker, pakaian kerja, dan sepatu kerja.

\section{Hubungan Kelengkapan Pemakaian Alat Pelindung Diri (APD) terhadap Kejadian Dermatitis Kontak}

Alat pelindung diri merupakan salah satu pilihan pertama yang digunakan untuk mengontrol sebuah paparan. Alat pelindung diri ini dapat terdiri dari kacamata, pakaian kerja, sepatu boot, sarung tangan serta masker yang mempunyai fungsi masing-masing sesuai tubuh yang akan dilindungi. Perlindungan praktek ini sangat sesuai untuk penerapan dalam bentuk mengontrol paparan luar, meski demikian alat pelindung diri ini bukan ditujukan sebagai bentuk tunggal mengontrol paparan.

Sebagai contoh penggunaan alat pelindung diri berupa sarung tangan, sarung tangan bisa menunjukkan masalah yang sedang dihadapi ketika mengontrol paparan pada pekerja sebagai bentuk kontrol utama. Pemakaian sarung tangan sebaiknya harus paham terhadap sifat paparan dan pemilihan sarung tangan yang tepat sehingga dapat memberikan perlindungan terhadap tangan. Sehingga perlunya berbagai tipe sarung tangan yang digunakan sesuai sifat paparan. Para pekerja harus memahami tipe dan risiko kulit dalam penggunaan sarung tangan yang tepat untuk setiap pekerjaan. Para pekerja perlu tahu 
cara memeriksa sarung tangan sebelum pemakaian. Setiap pekerja harus memakai sarung tangan yang benar saat terpapar risiko pekerjaan.

Sebagai pekerja yang bertugas melakukan pemilahan sampah dan pembuatan kompos di Rumah Kompos Jambangan Surabaya, pekerja harus berkontak langsung dengan substan/bahan sampah. Saat memilah sampah dan membuat kompos para pekerja menggunakan tangan sebagai salah satu bagian tubuh yang kontak langsung dengan substan/bahan sampah. Hal ini dapat memungkinkan terjadinya penyakit dermatitis kontak pada pekerja. Maka dari itu pentingnya penggunaan alat pelindung diri (APD) saat bekerja serta kewajiban sebagai tempat kerja untuk menyediakan alat pelindung diri (APD) yang memiliki standar bagi pekerja.

Berdasarkan hasil penelitian kelengkapan pekerja dalam menggunakan alat pelindung diri (APD) menunjukkan bahwa pekerja yang lengkap menggunakan alat pelindung diri sebanyak 23,8\% dan yang tidak lengkap menggunakan alat pelindung diri sebanyak $76,2 \%$. Sebanyak $66,7 \%$ yang tidak lengkap memakai alat pelindung diri mengeluhkan adanya gejala dermatitis kontak setelah bekerja dan berkontak langsung dengan sampah. Hal ini disebabkan walaupun pekerja saat berkontak langsung dengan sampah menggunakan alat pelindung diri lengkap namun pekerja tidak memakai alat pelindung diri sesuai standar dan yang telah disediakan oleh tempat kerja. Sebagian pekerja yang telah memakai alat pelindung diri seperti sarung tangan, mereka tidak memakai sarung tangan yang sesuai. Sarung tangan tersebut berbahan kain dan mereka melapisinya dengan plastik tipis. Namun, hal itu tidak menjamin pekerja tidak mengalami dermatitis kontak sebab alat pelindung diri seperti itu tidak dapat melindungi tubuh pekerja dari substan/ bahan sampah secara maksimal. Menurut Saftarina (2015), menyatakan bahwa terdapat hubungan antara penggunaan APD dengan kejadian dermatitis kontak akibat kerja pada petugas cleaning service di RSUDAM Provinsi Lampung. Petugas yang tidak menggunakan APD berisiko 2,71 kali untuk terkena dermatitis kontak akibat kerja dibanding petugas yang mengenakan APD. Hal ini sejalan dengan penelitian Chotimah (2006), di TPA Tanjung Rejo Kecamatan Jekulo Kabupaten Kudus Tahun 2006, bahwa adanya hubungan antara penggunaan sarung tangan dengan kejadian dermatitis kontak pada pemulung. Hal ini dapat terjadi karena penggunaan APD sangatlah penting.
Sehingga dapat disimpulkan bahwa pekerja di Rumah Kompos Jambangan Surabaya yang mengalami dermatitis kontak yang berkontak langsung dengan substan/bahan sampah saat bekerja disebabkan oleh kelengkapan pemakaian alat pelindung diri yang tidak sesuai standar menurut Peraturan Menteri Tenaga kerja dan Transmigrasi Republik Indonesia No. Per 08/ MEN/VII/2010 Tentang Alat Pelindung Diri.

\section{Hubungan Karakteristik Pekerja terhadap Kejadian Penyakit Dermatitis Kontak}

\section{Jenis Kelamin, Riwayat Alergi Kulit dan Usia}

Menurut Djuanda (2007), penyakit dermatitis kontak dapat dialami oleh semua manusia dari segala kalangan. Faktor karakteristik individu yang dapat mempengaruhi penyakit dermatitis kontak adalah jenis kelamin, riwayat alergi serta usia di mana usia lanjut lebih mudah terkena penyakit dermatitis kontak.

Berdasarkan hasil penelitian jenis kelamin pekerja di Rumah Kompos Jambangan Surabaya adalah jenis kelamin yang mendominasi pekerja di rumah kompos ini lebih banyak pekerja laki-laki. Sehingga didapatkan hasil bahwa pekerja berjenis kelamin laki-laki yang mengalami dermatitis kontak sebanyak 14 orang $(66,7 \%)$. Pekerja dengan jenis kelamin perempuan yang mengalami dermatitis kontak sebanyak 2 orang $(9,5 \%)$.

Penyakit dermatitis kontak dapat menyerang siapa saja, namun jenis kelamin yang banyak dijumpai terkena penyakit dermatitis kontak yaitu perempuan sebab perempuan lebih berisiko terhadap penyakit kulit akibat kerja jika dibandingkan jenis kelamin laki-laki. Lapisan kulit perempuan lebih sedikit menghasilkan minyak yang berguna untuk menjaga dan melindungi kelembapan kulit, selain itu kulit perempuan lebih tipis daripada kulit laki-laki sehingga penyakit dermatitis kontak lebih rentan untuk diderita oleh perempuan. Namun, proporsi pada penelitian ini sebagian besar berjenis kelamin laki-laki, sehingga tidak dapat mewakili kelompok jenis kelamin perempuan.

Riwayat alergi kulit pekerja di Rumah Kompos Jambangan Surabaya sebanyak 21 orang (100\%) pekerja tidak ada yang memiliki riwayat alergi kulit yang dapat menyebabkan dermatitis kontak. Berdasarkan hasil diatas, pekerja yang mengalami dermatitis kontak semuanya tidak memiliki riwayat alergi kulit baik itu responden sendiri dan orang 
tua responden. Menurut teori Cohen (1999) dalam Annisa (2010), mengatakan bahwa ketika salah satu orang tua yang memiliki alergi maka dapat memungkinkan menurunkan risiko alergi juga terhadap anaknya sekitar $20-40 \%$. Namun, pada penelitian ini tidak ada pengaruh riwayat alergi kulit keluarga sebab tidak adanya riwayat dari seluruh pekerja dimana pekerja yang mengalami dermatitis kontak ini dapat terjadi karena disebabkan pekerja berkontak langsung dengan bahan/substansi sampah saat bekerja di rumah kompos Jambangan Surabaya.

Usia merupakan salah satu unsur yang tidak dapat dipisahkan dari individu. Selain itu usia juga merupakan salah satu faktor yang dapat memperpanjang terjadinya dermatitis kontak. Sesuai sisi usia, umur 15-24 tahun merupakan usia dengan insiden penyakit kulit akibat kerja tertinggi. Hal tersebut disebabkan pengalaman yang masih sedikit dan kurangnya pemahaman mengenai kegunaan alat pelindung diri.

Berdasarkan hasil penelitian usia pekerja terhadap kejadian dermatitis kontak di Rumah Kompos Jambangan Surabaya adalah dari 21 pekerja (100\%) yang mempunyai usia 15-39 tahun yang mengalami dermatitis kontak terdapat sebanyak $71,4 \%$. Kemudian pekerja yang berusia $>64$ tahun sebanyak 1 orang $4,8 \%$ namun tidak mengalami dermatitis kontak. Walaupun usia tersebut usia pekerja yang tertua namun tidak mengalami dermatitis kontak. Berdasarkan hasil tersebut, dapat dikatakan bahwa usia di bawah 40 tahun banyak yang mengalami dermatitis kontak. Sejalan dengan penelitian Lestari (2007), menyatakan bahwa pekerja dengan usia muda mempunyai peluang 2,8 kali terkena dermatitis kontak dibandingkan dengan pekerja tua.

Berdasarkan uraian di atas dari ketiga faktor karakteristik pekerja pada Rumah Kompos Jambangan Surabaya dapat disimpulkan ketiganya tidak ada pengaruh dalam penyebab terjadinya dermatitis kontak pada pekerja di Rumah Kompos Jambangan Surabaya dikarenakan baik ketiga faktor karakteristik tersebut memiliki rasa tanggung jawab yang berbeda namun memiliki kapasitas kemampuan yang sama dalam melakukan pekerjaannya.

\section{Pengetahuan, Sikap dan Tindakan}

Berdasarkan hasil penelitian menurut pengetahuan pekerja di Rumah Kompos Jambangan Surabaya yang termasuk dalam kategori sedang dan mengalami dermatitis kontak sebanyak
47,6\%, hal ini terjadi karena para pekerja kurang memahami dermatitis kontak dari aspek pengertian dan penyebab dermatitis kontak. Pekerja dengan kategori baik dan tidak mengalami dermatitis kontak sebanyak $23,8 \%$, hal ini terjadi karena mereka mengetahui dampak pekerjaan mereka yang dapat menyebabkan dermatitis kontak sehingga mereka lebih memahami bagaimana cara pencegahan. Berdasarkan data tersebut walaupun pekerja ratarata memiliki pengetahuan yang sedang mengenai dermatitis kontak, namun tetap memiliki risiko dermatitis kontak sebab pengetahuan tersebut tidak diterapkan dalam menjalankan pekerjaannya selama bekerja dan di luar pekerjaan.

Berdasarkan teori Notoatmodjo (2007), pengetahuan mengandung enam unsur tingkatan yaitu tahu, memahami, aplikasi, analisis, sintesis, dan evaluasi. Pekerja yang memiliki pengetahuan yang kurang dapat dikatakan pekerja tersebut belum memahami tentang dermatitis kontak, sedangkan untuk responden yang memiliki pengetahuan baik dan sedang, dapat dikatakan pekerja telah mengetahui mengenai dermatitis kontak tetapi belum dapat memahami dan mengaplikasikannya. Menurut Liswanti (2015), salah satu faktor predisposisi yang mempengaruhi status kesehatan seperti dermatitis kontak adalah tingkat pendidikan dan pengetahuan sehingga pekerja yang memiliki pengetahuan yang baik harus dapat menerapkan dalam aktivitas seharihari sehingga pekerja yang belum tahu dapat menjadi tahu.

Berdasarkan uraian di atas, dapat disimpulkan bahwa pekerja yang memiliki pengetahuan yang baik dan sedang tetap dapat mengalami dermatitis kontak. Hal ini dikarenakan kurangnya kesadaran pekerja dalam menerapkan pengetahuan yang dimiliki saat bekerja. Penelitian ini sesuai dengan penelitian Annisa (2010) menyatakan tidak ada hubungan antara pengetahuan dengan kejadian dermatitis kontak sebab pekerja yang terkena dermatitis kontak dengan pengetahuan baik 50\% atau kurang sebanyak $50 \%$, keduanya menunjukkan bahwa walaupun pekerja memiliki pengetahuan yang baik mengenai dermatitis, tetap memiliki risiko dermatitis kontak. Sehingga perlunya penerapan pengetahuan kepada pekerja dengan pengetahuan baik agar dapat menjalankan dan menerapkan pengetahuan yang dimilikinya dalam menjalankan aktivitasnya selama bekerja dan di luar kerja.

Sikap pekerja di Rumah Kompos Jambangan Surabaya masuk dalam kategori baik dan mengalami dermatitis kontak sebanyak $57,1 \%$, ini disebabkan 
karena pekerja mengetahui cara pencegahan dermatitis tapi tidak menerapkan dalam bekerja. Sebanyak $23,8 \%$ yang tidak mengalami dermatitis kontak, mereka telah mengetahui cara pencegahan dampak dari pekerjaan tersebut yang dapat mencegah dermatitis kontak

Sikap merupakan reaksi atau respons seseorang yang masih tertutup terhadap suatu stimulus atau objek. Manifestasi sikap tidak dapat langsung dilihat, tapi hanya dapat ditafsirkan dari perilaku tertutup (Notoatmodjo, 2007). Berdasarkan hasil tersebut didapatkan walaupun dalam penilaian sikap para pekerja ini dalam kategori baik namun tidak menutup kemungkinan pekerja tetap dapat mengalami dermatitis kontak. Sehingga tidak adanya hubungan sikap pekerja dengan kejadian dermatitis kontak. Penelitian ini sejalan dengan penelitian Susetiati (2008), menyatakan bahwa perilaku dalam sikap pekerja terbukti bukan merupakan faktor risiko terjadinya dermatitis kontak. Baik sikap dalam berperilaku rendah atau tinggi dapat terkena dermatitis kontak. Hal ini dikarenakan mereka telah mengetahui sikap bagaimana cara mencegah agar tidak mengalami penyakit dermatitis kontak namun pekerja dalam melakukan pencegahan dermatitis kontak kurang diterapkan dalam mereka bekerja sehari-hari. Sehingga pekerja perlu menerapkan apa yang mereka ketahui dalam pencegahan dermatitis kontak.

Tindakan pekerja di Rumah Kompos Jambangan Surabaya dalam personal hygiene masuk dalam kategori baik. Sebesar 76,2\% mengalami adanya dermatitis kontak dan 5 orang $23,8 \%$ tidak mengalami dermatitis kontak. Tindakan pekerja di Rumah Kompos Jambangan Surabaya dalam penggunaan APD sebesar $66,7 \%$ mengalami dermatitis masuk dalam kategori sedang dan 14,3\% dalam kategori baik tidak mengalami dermatitis kontak.

Hal ini dikarenakan pekerja tahu bagaimana harus bertindak dalam kehidupan sehari-hari agar tidak terkena dermatitis kontak. Namun, dalam hal cuci tangan rata-rata dari mereka hanya melakukan hal tersebut saat sebelum makan serta menggunakan air tidak mengalir dan menggunakan sabun. Sehingga, dapat disimpulkan bahwa kurangnya kemauan dan fasilitas pendukung dalam bertindak yang dapat memungkinkan pekerja malas dan dapat mengalami dermatitis kontak.

Sesuai dengan teori bahwa dalam suatu tindakan tidak akan dapat langsung terwujud, namun terwujudnya suatu tindakan yaitu salah satunya meliputi dukungan dan fasilitas (Maulana, 2009). Menurut Mahyuni (2012), pekerjaan petugas kebersihan yang selalu berinteraksi dengan sampah yang juga berperan sebagai sumber penyakit sangat membutuhkan tindakan dan perilaku yang sehat. Terutama demi menjaga kesehatannya petugas kebersihan harus menjaga kebersihan dirinya atau personal hygiene. Penelitian ini sejalan dengan Susetiati (2008) menyatakan bahwa salah satu faktor penyebab dermatitis kontak adalah bukan dari perilaku dalam bertindak. Walaupun dalam tindakan pekerja baik belum tentu tidak dapat mengalami dermatitis kontak. Sehingga, perlunya kesadaran dari pekerja agar dapat meningkatkan personal hygiene pekerja dan selalu memakai alat perlindungan diri (APD) dalam bekerja sehari-hari.

\section{SIMPULAN}

Kelengkapan pemakaian APD (Alat Pelindung Diri) yang digunakan pekerja saat bekerja di Rumah Kompos Jambangan Surabaya tidak dipakai secara lengkap maupun telah disediakan oleh pihak kantor. Pekerja hanya memakai sarung tangan yang tidak sesuai dan layak yang memungkinkan bahan/substan dapat meresap ke tangan sehingga dapat menyebabkan pekerja mengalami dermatitis kontak.

Karakteristik individu meliputi pengetahuan masuk dalam kategori sedang, sikap masuk dalam kategori baik. Untuk jenis kelamin pekerja mayoritas adalah laki-laki sebesar 16 orang $(76,2 \%)$ dan 5 orang $(23,8 \%)$ wanita. Tidak ada satu pun pekerja yang memiliki riwayat alergi kulit keluarga. Serta untuk usia pekerja lebih banyak usia $<30$ tahun dengan rentang usia termuda 18 tahun dan yang tertua 75 tahun.

Personal hygiene masuk dalam kategori baik karena pekerja telah mengetahui bagaimana menjaga kebersihan dan kesehatan tubuh. Namun, kurangnya kesadaran dalam menerapkan dikehidupan seharihari.

Hasil dari hubungan antara kelengkapan pemakaian alat pelindung diri (APD) dan karakteristik pekerja Rumah Kompos Jambangan Surabaya dengan penyakit dermatitis kontak didapatkan hasil bahwa kelengkapan pemakaian alat pelindung diri (APD) merupakan faktor yang sangat mempengaruhi penyakit dermatitis kontak di Rumah Kompos Jambangan Surabaya. 


\section{DAFTAR PUSTAKA}

Annisa. 2010. Faktor-Faktor yang Berhubungan dengan Dermatitis Kontak Iritan pada Pekerja Pengolahan Sampah di TPA Cipayung Kota Depok Tahun 2010. Skripsi. Fakultas Kedokteran dan Ilmu Kesehatan UIN, Jakarta.

Ariesa. D. 2012. Kualitas Fisik dan Kimia Udara dalam Ruangan Rumah Kompos Bratang Surabaya. Skripsi. FKM Unair, Surabaya.

Chotimah, D. C. 2006. Hubungan Penggunaan Sarung Tangan dengan Kejadian Dermatitis Kontak Iritan pada Pemulung Sampah di TPA Tanjung Rejo Kecamatan Jekulo Kabupaten Kudus. Skripsi. IKM UNS, Semarang.

Dinas Kebersihan dan Pertamanan Kota Surabaya. 2016. Profil Dinas Kebersihan dan Pertamanan Kota Surabaya Tahun 2016. Surabaya.

Dinas Kesehatan Kota Surabaya. 2014. http://dinkes. surabaya.go.id/portal/index.php/profil/dkkdalam-angka/statistik-10-penyakit-terbanyak. Diakses tanggal 30 Maret 2016.

Djuanda. 2007. Ilmu Penyakit Kulitdan Kelamin. Jakarta: Fakultas Kedokteran Universitas Indonesia.

Keputusan Menteri Kesehatan Republik Indonesia No 1405 Tahun 2002 Tentang Persyaratan Kesehatan Lingkungan Kerja Perkantoran dan Industri.

Lestari, F., Utomo, H.S. 2007. Faktor-Faktor yang Berhubungan dengan Dermatitis Kontak pada Pekerja di PT Inti Pantja Press Industri. Makara Kesehatan,[e-journal] 11(2):pp.61-68. Tersedia di: <http://journal.ui.ac.id/index.php/health/ article/viewFile/257/253> [Sitasi 13 Januari 2017].

Liswanti, Y. 2015. Faktor-faktor yang Berhubungan dengan Kepatuhan Penggunaan APD Serta Kaitannya Terhadap Status Kesehatan pada Petugas Pengumpul Sampah Rumah Tangga di Kota Tasikmalaya Tahun 2014. Jurnal Kesehatan
Bakti Tunas Husada, [e-journal]13(1):pp.196200.Tersedia di: <http://ejurnal.stikes-bth.ac.id/ index. php/P3M/article/view/34> [Diakses tanggal 13 Januari 2017].

Mahyuni, E.L. 2012. Dermatosis (Kelainan Kulit) Ditinjau Dari Aspek Keselamatan dan Kesehatan Kerja pada Pemulung di TPA Terjun Medan Marelan. Media Kesehatan Masyarakat Indonesia,[e-journal] 11(2):pp.101-109. Tersedia di: $<$ http://ejournal.undip.ac.id/index.php/mkmi/ article/4832> [Sitasi 13 Januari 2017].

Maulana, H. D. J. 2009. Promosi Kesehatan. Jakarta: EGC.

Notoatmodjo, S. 2007. Ilmu Kesehatan Masyarakat. Jakarta: PT. Rineka Cipta.

Peraturan Menteri Tenaga Kerja dan Transmigrasi Republik Indonesia No. PER 8 Tahun 2010 tentang Alat Pelindung Diri.

Saftarina, F. 2015. Prevalensi Dermatitis Kontak Akibat Kerja dan Faktor yang Memengaruhinya pada Pekerja Cleaning Service di Rumah Sakit Umum Abdul Moelek. Media Kesehatan Masyarakat Indonesia,[e-journal] 11(2):pp.101109. Tersedia di <http://ejournal.undip.ac.id/ index.php/mkmi/article/4832> [Sitasi 13 Januari 2017].

Shenna. 2016. Penggunaan APD, Faktor Lingkungan, dan Karakteristik Pekerja terhadap Dermatitis Kontak Pekerja di Rumah Kompos Jambangan Surabaya. Skripsi, FKM Unair, Surabaya.

Sugiyono. 2007. Metode Penelitian Kuantitatif dan Kualitatif. Bandung: CV. Alfabeta.

Susetiati, D.A. 2008. Pengaruh Pengetahuan dan Perilaku Perajin Pandan terhadap Frekuensi Dermatitis Tangan di Desa Tanjungharjo, Nanggulan, Kulonprogo. Jurnal Ilmu Kesehatan Kulit dan Kelamin, 20(3):pp.212-216. 